\title{
Chemical Experts at the Royal Prussian Porcelain Manufactory
}

The royal porcelain manufactories in eighteenth-century Continental Europe were sites of production that implemented chemistry in three different areas: manufacture of porcelain paste, preparation of pigments for ornamenting porcelain, and construction of furnace along with choice of fuel for firing porcelain. This paper provides evidence for the Royal Prussian Porcelain Manufactory in Berlin being a site of chemistry by studying the activities of its socalled arcanists (Arcanisten), laboratory workers (Laboranten) and chemists between 1787 and 1795 . It pays particular attention to the questions of who implemented chemistry and how this was done.

\section{Introduction}

Porcelain was one of the most valued luxury goods in early modern Europe. Before the eighteenth century it was imported from China, and it was expensive. In 1708, the German apothecary and alchemist Johann Friedrich Böttger (1682-1719) found the recipe for European hard-paste porcelain, with support from Ehrenfried Walther von Tschirnhaus (16511708), mathematician and director of the chemical laboratory of the Saxon Elector Friedrich August I, the mining official Gottfried Papst von Ohain (1656-1729) as well as several laboratory assistants. In 1710, shortly after Böttger and Tschirnhaus had invented true porcelain made with China clay (or kaolin), August I founded the Porcelain Manufactory of Meissen, located in his castle (Albrechtsburg). By the end of the century, the Holy Roman 
Empire hosted some twenty porcelain manufactories, among which the state manufactories in Meissen, Vienna and Berlin were the most famous. ${ }^{1}$

Like the art of glass making and pottery, the manufacture of porcelain involved the transformation of materials by the use of fire. We might thus designate theses arts "chemical arts" or "chemical practices." This is not entirely unproblematic, however, as the glass makers and potters themselves did not always identify their art as a "chemical" or "alchemical" one. In the case of porcelain manufacture, the association with alchemy or chemistry appears to be clearer. Production of porcelain was a novel art in eighteenth-century Europe, established with the help of an alchemist's outstanding knowledge about materials and systematic chemical experimentation. If the initial invention of porcelain had taken years of painstaking chemical experimentation, its subsequent commercial production meant further, almost endless technical and artistic challenges. Most of the eighteenth-century porcelain manufactories in Continental Europe employed experts to cope with these challenges. Among these experts, several had come in contact with chemistry or were explicitly recognized as chemists. Despite the latter fact, however, some historians have argued that chemical science had no impact on eighteenth-century porcelain manufacture. ${ }^{2}$

There is a long historical tradition that has equated early modern science with natural philosophy or theories of nature. Furthermore, until the 1990s, the vast majority of historians of science and technology took it for granted that before the late nineteenth century science (identified with natural philosophy) and technology were clearly separate enterprises. This view has recently been challenged by many historical studies that provide compelling examples of intersecting scientific and technological activities long before the Industrial

\footnotetext{
${ }^{1}$ Otto Walcha, Meißner Porzellan (Gütersloh: Bertelsmann Lexikon-Verlag, 1975); Gustav Kolbe, Geschichte der Königl. Porzellanmanufaktur zu Berlin (Berlin: Verlag der Königlichen Ober-Hofbuchdruckerei, 1863); Erich Köllmann and Margarete Jarchow, Berliner Porzellan, Textband (München: Klinkhardt \& Biermann, 1987); Arnulf Siebeneiker, Offizianten und Ouvriers, Sozialgeschichte der Königlichen Porzellan-Manufaktur und der Königlichen Gesundheitsgeschirr-Manufaktur in Berlin 1763-1880 ( Berlin: Walter de Gruyter, 2002).

${ }^{2}$ Siebeneiker, Offizianten und Ouvriers, 145.
} 
Revolution. ${ }^{3}$ In their pioneering work on the industrial revolution in chemistry, published in 1952, Clow and Clow, too, highlighted the interconnection of chemical science and technology around 1800 . They studied, in particular, the "fundamentally chemical nature of the operations" involved in eighteenth-century pottery, which they also designated "skilled scientific operations". ${ }^{4}$ Thus they identified not just porcelain manufacture but early modern pottery more broadly as a site of chemistry. Clearly, this was a time when historians paid less attention to actors' terms than today. But what rendered an eighteenth-century workshop or a manufactory a "site of chemistry"? Under which conditions did the eighteenth-century historical actors recognize a practitioner involved in manufacture as a "chemist"?

In the following I try to get a more precise picture of the chemistry involved in porcelain manufacture. My study focuses on the Royal Prussian Porcelain Manufactory in Berlin, its laboratory, and experiments performed in it from 1787 until 1795. I will first provide an overview of the organization of the Manufactory. This will help to identify more exactly the distinct sites of chemistry as well as the social figures who can be reasonably called chemists or "chemical experts." The next part describes the way in which various types of chemical experts collaborated: through inspecting committees. This is followed by studies of concrete activities involving chemistry.

\footnotetext{
${ }^{3}$ I discuss this issue in detail in Ursula Klein "Chemistry in Eighteenth-Century Manufacture," forthcoming in Osiris. The literature on this issue has grown enormously. The most recent publications are: Eric H. Ash, ed., Expertise: Practical knowledge and the Early Modern State, Osiris 25 (2010); Bruno Belhoste, Paris Savant, Parcours et rencontres au temps des Lumières (Paris: Armand Colin, 2011); Sven Dupré and Christoph Lüthy, eds., Silent Messengers: The Circulation of Material Objects of Knowledge in the Early Modern Low Countries (New Brunswick and London: Transaction Publishers, 2011); Ursula Klein and E. C. Spary, eds., Materials and Expertise in Early Modern Europe: Between Market and Laboratory (Chicago: The University of Chicago Press, 2010); Ursula Klein, ed., "Artisanal-scientific Experts in Eighteenth-Century France and Germany," special issue of Annals of Science 69 (3), (2012); Lissa Roberts, Simon Schaffer, and Peter Dear, eds., Mindful Hand: Inquiry and Invention from the Late Renaissance to Early Industrialization (Amsterdam: Koninklijke Akademie van Wetenschappen, 2007); Pamela O. Long, Artisan/Practioners and the Rise of the New Sciences 1400-1600 (Corvallis: Oregon State University Press, 2011); Matteo Valeriani, Galileo Engineer (Dordrecht: Springer, 2010).

${ }^{4}$ Archibald Clow and Nan L. Clow, The Chemical Revolution: A Contribution to Social Technology (London: The Batchworth Press, 1952), 296.
} 


\section{Chemical experts in a system of division of labour}

The average pottery in early modern Europe was a small cottage that provided space for just one or two potters. There were also somewhat larger potteries, especially in early eighteenthcentury England, which had introduced some basic division of labour. As Clow and Clow pointed out, "in such a pottery six to eight men and boys worked, with separate sheds for thrower and decorator." They added: "each man, however, could carry out all of the operations if required." Hence, they concluded that "organization in early potteries was extremely simple." ${ }^{5}$

A totally different picture results, however, from studies of the eighteenth-century royal porcelain manufactories. The manufacture of porcelain was neither part of the tradition of European arts and crafts nor was it an art performed in a traditional workshop by just one type of artisan, the potter. Like state-directed mining, naval shipbuilding, the draining of fens, the construction of canals and so on, the royal porcelain manufactories belonged instead to the big industry of the time with a high degree of division of labour and complex technology, in which advanced experts played a crucial role. ${ }^{6}$ Thus the royal porcelain manufactories differed in important social and technical aspects not only from early modern potteries but also from apothecaries' shops, to mention another prominent site of eighteenth-century chemistry.

The Royal Prussian Porcelain Manufactory of Berlin was founded in 1763, at the end of the Seven Years War. It was a continuation of a private manufactory, located close to Leipziger Platz, which had initially been established between 1751 and 1755 by the entrepreneur Wilhelm Caspar Wegely and was then bought by the wealthy merchant Johann

\footnotetext{
${ }^{5}$ Clow and Clow, Chemical Revolution, 294-95.

${ }^{6}$ For these most advanced forms of eighteenth-century manufacture with a high degree of division of labor see the contributions in Ash, ed., Experts; Roberts et. al., ed., Mindful Hand; Klein, ed., "Artisanal-Scientific Experts."
} 
Ernst Gotzkowsky in 1761. When this merchant went bankrupt due to financial speculations during the Seven Years war Frederick II decided to buy the manufactory. ${ }^{7}$

Unlike a traditional pottery, the Royal Prussian Porcelain Manufactory was a true manufactory with a high degree of division of labour, complex organization, and comprising several buildings (see figure 1). In the Manufactory's mills, a group of workers crushed, grinded and purified the hard ingredients for porcelain paste (feldspar, quartz), while a second group of specialized workers (German: Schlämmer) blunged and purified the raw "porcelain earth" (a mixture of kaolin and quartz) ${ }^{8}$ Supervised by the Manufactory's most important chemical experts, the "Arcanisten," another group of specialized workers then made the porcelain paste. In the next step different groups of workers (German: Former, Dreher, Bossierer) formed dishes and various kinds of figures out of the paste, which were subsequently fired by specialists (German: Verglühbrenner) at a temperature of $900^{\circ} \mathrm{C}$ (figure 2). ${ }^{9}$ This was followed by glazing, performed by yet another group of workers (German: Glasurer). Then came a second round of firing at a temperature of ca. $1450^{\circ} \mathrm{C}$, done by the Glasurbrenner, followed by polishing (Schleifer, Polierer). Furthermore, in the Manufactory’s “pigment laboratory” the so-called laboratory workers (Laboranten) prepared pigments, fluxes and oils for painting on porcelain, which were used by the painters for over-

\footnotetext{
${ }^{7}$ The question of why Frederick II was willing to buy the porcelain manufactory-so soon after a long and expensive war is difficult to answer. It certainly fit the general mercantilist policy of Frederick II and his wish to represent the glory of Prussia (Siebeneicker, Offizianten und Ouvriers, 19-23). But, on the other hand, we also know that ten years earlier, in 1753, the King had clearly stated: "We are not inclined to establish a porcelain factory at our expense." Geheimes Staatsarchiv Preussischer Kulturbesitz (herafter GStA PK), I. HA Geheimer Rat, Rep. 9 Allgemeine Verwaltung, E 16 II, Fasc. 3, folio 14.

${ }^{8}$ My description of the different parts of the manufacture of porcelain is simplified. For more details see Siebeneicker, Offizianten und Ouvriers, 87-117

${ }^{9}$ Figure 2 shows in the foreground of the building on the left a man who is blunging porcelain earth, which is then dried on a wall depicted in the background; firing is shown on the left. The second building on the right depicts crushing of raw material and forming of porcelain in the background: Comte de Milly, Die Kunst das ächte Porcellan zu verfertigen, translated and annotated by Daniel Gottfried Scherber (Königsberg and Leipzig: Johann Jakob Kanter, 1774; reprint Leipzig: Zentralantiquariat der Deutschen Demokratischen Republik, 1977), plate 1. Comte de Milly described porcelain manufacture in Germany (in the city of Ludwigsburg), which he had observed in the early 1760s; see Arnuf Siebeneiecker, "Produktionsprozesse in der Manufaktur F. A. Schumann, Zur Porzellantechnologie im 19. Jahrhundert," in Dietmar Jürgen Ponert, Die Porzellanmanukatur F. A.

Schumann in Moabit bei Berlin (Berlin: Scherer. 1993), 89-111.
} 
glaze ornamenting and subsequent enamelling (at a temperature of ca. $800^{\circ} \mathrm{C}$ ). The Manufactory's officials designed and supervised all of these different parts of labour.

At the time of its foundation in 1763, the Manufactory employed 134 workers, designated ouvriers, and twelve officials or Offizianten..$^{10}$ Two years later the number of workers doubled, and in the 1780s it further increased to an average of 350-400; among them were also children and women. ${ }^{11}$ At the same time the number of officials increased to more than thirty. Around 1770 around 41\% of the Manufactory's ouvriers were highly qualified artists and craftsmen who had been apprenticed to a master of the Manufactory for generally six to seven years, and were relatively well paid. To this group belonged painters and the artistic workers forming the porcelain as well as instrument makers, and laboratory workers. Around 36\% of the Manufactory's workers were less qualified people, responsible, for example, for firing the furnaces and for glazing and polishing porcelain ware. The remaining $23 \%$ were workers without significant training, who performed simple, but often physically demanding labour in the mill, furnace house, stable and so on.

The corps of officials consisted of the Manufactory's two directors, accountants and other specialists for commerce along with their assistants (around 60\% around 1790) as well artistic and technical experts and their assistants (around 40\%). To the latter group of expert officials belonged the masters of painting and modelling, who were responsible for design and supervision of the groups of artistic ouvriers. The most important technical experts were the Manufactory's two arcanists (Arcanisten) - men who knew the secret (lat. arcanum) of how to make porcelain paste. As we will see below, they were clearly knowledgeable in chemistry. They performed quality control and chemical analysis of materials, calculated the proportions of ingredients for the porcelain paste, and supervised the workers who actually weighed the

\footnotetext{
${ }^{10}$ The following two paragraphs are based on Siebeneicker, Offizianten und Ouvriers, 236-248.

${ }^{11}$ According to Siebeneiker, the Manufactory employed children and women from the late 1790s (Siebeneicker, Offizianten und Ouvriers, 308-315). But as early as 1763 Frederick II ordered that orphans from the orphanage of Potsdam were to be employed in his Manufactory; GStA PK, 1 HA Geheimer Rat, Rep. 9 AV, E 166 II, Fasc. 3, folio 17,21 .
} 
ingredients, mixed them and made the paste. ${ }^{12}$ They also supervised the firing of the porcelain, and performed technological experiments. The laboratory workers knew another part of the Manufactory's Arcanum: the preparation of pigments and enamelling. They also carried out experiments for improving pigments and extending the spectrum of colours. In the reorganization of the Manufactory in 1786/7 (see below), the laboratory workers, too, were promoted to the group of officials.

The manufacture of porcelain in the Manufactory involved many different practical sectors that were distributed among different groups of workers and officials. In this system of division of labour, the majority of workers and officials had loose or no connections with chemistry. By contrast, there was a small subgroup of practitioners, all belonging to the group of officials after 1787, who performed activities that involved chemical knowledge: two or three laboratory workers and two arcanists. These men were "experts" (German: Sachverständige) in the sense of specialized practitioners who possessed outstanding technical and natural knowledge and were recruited by the State. ${ }^{13}$ They may also be defined more narrowly as "chemical experts."

In the system of division of labour, the technical experts of the royal porcelain manufactories, in Prussia and elsewhere, were working in sectors of manufacture that were crucial for the outcome of manufacture and at the same time were sites of challenges. The arcanists continually struggled to find the best mixture for porcelain paste out of locally varying ingredients, and they were further confronted with demands for inventing new varieties of porcelain. Arcanists and workers in charge of the furnaces, who were faced with

\footnotetext{
${ }^{12}$ Siebeneicker, Offizianten und Ouvriers, 101. It should be noted that our historical information about the workers of the Manufactory is incomplete. It would be particularly interesting to have more information about the workers who made the porcelain paste and those who were responsible for firing the porcelain. In addition to the laboratory workers, these two groups were also supervised by the Arcanisten, the most important group of chemical experts. But we know nothing about interactions and exchange of knowledge between them and the arcanists.

${ }^{13}$ For the notion of expert used here see Eric H. Ash, "Expertise and the Early Modern State," in Ash, ed., Expertise, 1-14; Ursula Klein, "Introduction: Artisanal-scientific experts in Eighteenth-century France and Germany," in Klein, ed., "Artisanal-Scientific Experts," 303-306.
} 
an increasing shortage of wood, tried to find substitutes for it and to improve furnaces. Laboratory workers preparing pigments, fluxes, and oils for painting on porcelain were seeking ways to maintain the quality of long used pigments and further experimented with new materials for extending the spectrum of colours and varying ornamentation.

In addition to these internal experts, the State administration invited savants recognized as chemists to become members of committees to inspect the Manufactory and to promote experiments for innovation. As we will see below, the board of the Manufactory had recruited the well-known chemist Martin Heinrich Klaproth as a member of an inspecting committee. In a similar way, the Royal Porcelain Manufactory of Sèvres employed the two French chemists Jean Hellot and Pierre-Joseph Macquer. ${ }^{14}$ The royal porcelain manufactories in Prussia and France were organized by the State. In both cases the State administration involved learned chemists, who were members of scientific academies, in inspections of manufacture and experimentation.

These external chemical experts brought additional chemical knowledge into manufacturing. Collaborating with the Manufactory's laboratory workers and arcanists, and sometimes formally teaching them, they promoted the circulation of chemical knowledge among different groups of experts permanently employed in the Manufactory. The collaboration of different types of experts was organized by the State. The arcanists, laboratory assistants (Laboranten) and chemists participating in inspecting committees were experts of the State.

\section{Arcanists, Laboratory workers, and Chemists}

Under the reign of Frederick II, the Manufactory was directly subordinated to the King. Its director, Johann Georg Grieninger, managed daily business, but the King reserved important

\footnotetext{
${ }^{14}$ Christine Lehman, "Pierre Joseph Macquer an Eighteenth-Century Artisanal-Scientific Expert," in Klein, ed., "Artisanal-Scientific Experts," 307-333.
} 
decisions for himself. ${ }^{15}$ In 1786/7, shortly after Frederick William II had ascended the throne, the Manufactory was reorganized on several levels, which had consequences for the status of chemistry. ${ }^{16}$ In August 1786, the new King nominated a second director, Carl Jacob Christian Kipfel, who had previously been the supervisor of painters and inspector of materials (Warenlagerinspektor). In April 1787 the influential Minister Friedrich Anton von Heinitz (1725-1802), who had long been in charge with the administration of the Prussian mining and smelting industry, convinced the King to establish an administrative board (the Porzellanmanufaktur-Kommission). ${ }^{17}$ The new board consisted of the former two directors, a mining councillor named Friedrich Philipp Rosenstiel (1754-1832), who worked in Heinitz's Mining and Smelting Department, and Heinitz himself as the committee's president. In this way Heinitz linked the Manufactory to the general Prussian State administration in Berlin, the Generaldirektorium, although the King remained formally at the top of the administrative hierarchy.

After the reorganization of the Manufactory in 1786/7, the status of the chemical experts changed significantly. Before 1787, one of the Manufactory's two arcanists had an artisanal background, whereas the other one was a university-educated man, who, following a personal order of Frederick II, was also "a good chymist." ${ }^{18}$ In this, the King was presumably stimulated by the example of the Porcelain Manufactory of Meissen, which employed university-educated arcanists (mostly physicians) since $1731 .{ }^{19}$ From spring 1766 the physician Wilhelm Kretschmann (unknown-1774) was "Chymicus and Arcanist" of the Royal

\footnotetext{
${ }^{15}$ Accordingly, under the reign of Frederick II profit of the Manufactory was transferred to the King's treasury (Dispositionskasse). Siebeneicker, Offizianten und Ouvriers, 462.

${ }^{16}$ Siebeneicker, Offizianten und Ouvriers, 24, 30-33.

${ }^{17}$ The Minister's name was first written "Heynitz," but during his stay in Prussia it changed to "Heinitz." On this influential Minister see Wolfhard Weber, Innovationen im frühindustriellen deutschen Bergbau und Hüttenwesen: Friedrich Anton von Heynitz (Göttingen: Vandenhoeck \& Ruprecht, 1976).

${ }^{18}$ Johann Georg Grieninger, "Vom Ursprung und Fortgang der Königlichen Aechten Porzellän Manufactur zu Berlin,” in Erich Köllmann and Margarete Jarchow, Berliner Porzellan, Textband (München: Klinkhardt \& Biermann, 1987), 278-292, 284; Siebeneiker, Offizianten und Ouvriers, 145.

${ }^{19}$ Walcha, Meißner Porzellan, 85, 125.
} 
Porcelain Manufactory. ${ }^{20}$ After his death in 1774, the physician and chemist Dr. Johann Friedrich Schopp (unknown-1797) became his successor. After 1787, however, the difference between university-educated and artisanal arcanists almost disappeared, as the latter received formal chemical training as well.

Heinitz's reorganization of the Manufactory also involved steps for a more formal chemical training of the laboratory workers, which further changed the relationship between the laboratory workers and the arcanists. Before 1787 , the laboratory workers belonged to the group of ouvriers, whereas the arcanists were officials. The reforms in 1786/7, however, elevated the laboratory workers to the rank of officials. ${ }^{21}$ In close connection with this social change, the technical relationship between the arcanists and the laboratory workers changed as well. The early arcanists were responsible only for the production of porcelain paste and the firing of porcelain, but not for the so-called pigment laboratory (Farbenlaboratorium), where painters and laboratory workers prepared pigments, fluxes and oils for ornamenting porcelain. The first supervisor of the pigment laboratory was the court painter Johann Christoph Jucht from the duchy of Ansbach, who had been personally hired by Frederick II in 1764. ${ }^{22}$ Again, the King emulated the Meissen Manufactory, where the manufacture of pigments was long organized by the court painter Johann Gregorius Höroldt. ${ }^{23}$

The laboratory of the Berlin Manufactory was originally primarily a place of production, which resembled a kitchen. After 1787 it was transformed into chemical laboratory. From this time the laboratory became a site of more frequent chemicaltechnological experimentation. Small-scale manufacture of pigments facilitated technological experimentation, as the notorious issue of scaling up was not a problem here. In order to promote and secure these changes, Heinitz abolished the distinction between the two Arcana,

\footnotetext{
${ }^{20}$ Grieninger, "Vom Ursprung und Fortgang," 278-292, 284.

${ }^{21}$ The first laboratory worker elevated to the status an official in 1786 was a man named Johann C. E. Riedel, see Siebeneicker, Offizianten und Ouvriers, 222.

${ }^{22}$ Siebeneicker, Offizianten und Ouvriers, 147.

${ }^{23}$ Walcha, Meißner Porzellan, 48-71, 82-84.
} 
put the laboratory in the hands of the arcanists, organized formal chemical teaching of both laboratory workers and arcanists, and requested written experimental reports. An order of the King, pronounced in 1791, sanctioned this transformation. ${ }^{24}$

The reorganization of the Manufactory in 1786/7 also affected the role played by the external chemical experts. The Manufactory had long received occasional support from savants, who lived in Berlin, were members of the Royal Prussian Academy of Sciences and were recognised as chemists or mineralogists. In the late 1770s the Prussian mining councillor, chemist and mineralogist Carl Abraham Gerhard (1738-1821) studied cobalt ore, smalt and bleu royal, to be used as a pigment for porcelain. ${ }^{25}$ Around the same time, another chemist and member of the Royal Prussian Academy of Science performed experiments at the Manufactory: Franz Carl Achard (1753-1821). ${ }^{26}$ In 1779 the King ordered the Manufactory's laboratory workers to perform experiments for the preparation of bleu mourant (dying blue), a light blue colour, which was produced at Sèvres from 1753 but was still lacking at the Manufactory. ${ }^{27} \mathrm{He}$ further asked Achard to support these experiments by his "chemical knowledge." ${ }^{28}$ On 15 January 1780, the King pronounced that: "the professor of chymistry Franz Karl Achard created several samples of bleu mourant, which must now be submitted to further assays in the manufactory, be carefully applied on porcelain and then tried in the fire. ${ }^{29}$ As a result of these experiments, the Manufactory created in 1784 its new decoration

\footnotetext{
${ }^{24}$ For this order, pronounced on 26 May 1791 see GStA PK, I. HA Rep. 151 Finanzministerium, Abt. IC, Nr. 9469, folio 64-71.

${ }^{25}$ Carl Abraham Gerhard 1779, "Nouvelle Méthode d'extraire le Bleu royal de toutes sortes de Cobalt à l'usage des Fabriques de Porcelaine," Nouveaux Mémoires de L'Académie Royale (1779): 12-19. On Gerhard see Ursula Klein, "Savant Officials in the Prussian Mining Administration," in Klein, ed., "Artisanal-Scientific Experts," 349-374.

${ }^{26}$ On Achard see Hans-Heinrich Müller, Franz Carl Achard, 1753 bis 1821 (Berlin: Verlag Dr. A. Bartens, 2002).

${ }^{27}$ The Meissen Manufactory imitated bleu royal from 1765; Walcha, Meißner Porzellan, 163.

${ }^{28}$ Archive of the Royal Prussian Porcelain Manufactory (hereafter KPM archive) XVII. 12 (Acta die Untersuchung des Farben-Laboratorii ... betreffend), folio 8 [2].

${ }^{29}$ Quoted in Claudia Tetzlaff and Hartmut Krohm, KPM Welt, ein Handbuch zur Ausstellung KPM-Welt (Berlin: Königliche Porzellan-Manufaktur Berlin $\mathrm{GmbH}, 2007)$, 75. According to Tetzlaff and Krohm, the Royal Porcelain Manufactory of Berlin $(K P M)$ is still using this recipe today and keeps it secret.
} 
bleu mourant and immediately applied it to a new dinner-service for the King, which visitors of German museums can still admire today. ${ }^{30}$

Before 1787, the external chemical experts were involved only occasionally for solving particular problems. After the Manufactory's reorganisation they collaborated on a more regular basis with the Manufactory's laboratory workers and Arcanisten. As we shall see below, the most important mechanism for this collaboration were State committees.

\section{Inspection of the Manufactory's Laboratory}

Shortly after its inception the new board organised inspections of three technical sectors of the Manufactory: the preparation of paste; the laboratory and preparation of pigments (along with fluxes and oils); and the furnaces along with an examination of ways to save fuel.

The inspecting committee for the pigment laboratory was set up on 4 July 1787 with Rosenstiel, a good administrator, as its head and the arcanist Schopp and the chemist Klaproth as its two technical experts. Martin Heinrich Klaproth (1743-1817) had been teaching chemistry at the Berlin medical surgical school (Collegium medicochirurgicum) since 1782, at the so-called Mining Academy of Berlin since $1784,{ }^{31}$ and his public lectures on chemistry attracted a large audience in Berlin, among them many women. Klaproth was not university-educated but rather an apothecary who had received an ordinary pharmaceutical apprenticeship. Until 1800, when he became the director of the laboratory of the Royal Prussian Academy of Sciences and sold his shop, he experimented in his pharmaceutical laboratory. In 1788 he became a member of the

\footnotetext{
${ }^{30}$ Tetzlaff and Krohm, KPM Welt, 75.

${ }^{31}$ On Klaproth see Georg Edmund Dann, Martin Heinrich Klaproth, 1743-1817 (Berlin: Akademie Verlag, 1958). The so-called Mining Academy of Berlin had been founded in 1770. However, compared with the Mining Academies of Freiberg and of Schemnitz, the Berlin institution was not a true school or academy, but rather a series of lectures, organized by the Mining and Smelting Department. See Ursula Klein, "Ein Bergrat, zwei Minister und sechs Lehrende: Versuche der Gründung einer Bergakademie in Berlin um 1770," in NTM 18 (2010): 437-468.
} 
Royal Prussian Academy and was thus formally recognized as a savant

\section{(Naturforscher).}

The inspection committee was charged with carrying out "an exact examination of the pigment laboratory of the Manufactory" its instruments and furnaces, raw materials, laboratory workers' techniques and whether they "worked with exactitude and cleanliness and according to the good principles of chemical science." In addition, it was to examine the quality of the finished pigments and determine "whether all of them possessed the required egalité, so that it was certain that they always yielded the same effects when used in painting." ${ }^{32}$ The latter item was, in more modern terms, a quest for standardization. The commission was expected to propose improvements in all these areas and "to perform chemical experiments." These were to examine existing recipes which were the personal knowledge of the laboratory workers and to develop new pigments as well as a flux to replace minium (a lead oxide), which often caused unwanted changes in the colours. ${ }^{33}$ As the director Grieninger pointed out it would be of great use:

if a skilled chymicus, who is also a good mineralogist, would set out to study in greater detail the still quite obscure knowledge (dunkle Lehre) about the preparation of enamel pigments for painting on true porcelain as well as the most advantageous minerals used [for this purpose], and illuminate [the issue] by his experiments and observations. ${ }^{34}$

\footnotetext{
${ }^{32}$ KPM archive, XVII. 12, folio 9 [3].

${ }^{33}$ KPM archive XVII. 27 (Acta das Arcanum und Farben Laboratorium ... betreffend), folio 5 [3|.

${ }^{34}$ KPM archive XVII. 27, folio 6 [4].
} 


\section{The Laboratory's Transformation: Chemical Purity and Cleanliness}

The committee was expected to carry out its inspection and present its report by October $1787 .{ }^{35}$ But it was only on 22 June 1789 that Rosenstiel was able to present the report, which, he conceded, was still incomplete and preliminary. ${ }^{36}$ As Klaproth had been too busy with other occupations, he explained, they had "lacked time and opportunity to perform many of the wanted experiments with the precision and careful repetition that would be necessary to reach the conviction of the usefulness of our suggestions." 37

Nonetheless, the overall tone of their report was very critical. They noted the absence of good furnaces, balances, vessels, cabinets for storing materials and many tools, "whose lack," they stated, was "utterly unpleasant for a clean chemist (reinlicher Chemist)." ${ }^{38}$ They had even observed that the laboratory workers sometimes used their bare hands instead of ladles to take substances out of vessels. The lack of chemical instruments meant that the laboratory workers did not precisely weigh the ingredients for preparing pigments and fluxes. Furthermore, many of the materials were neither pure nor well stored and ordered. The report emphasised the importance of standardising the ingredients for the preparation of pigments and fluxes. Although they did not use the term "standardisation," Rosenstiel and Klaproth's quest for "unchanging equality of quality (beständig gleiche Güte)" of materials meant the same. ${ }^{39}$ The Manufactory purchased the ingredients for its pigments ad hoc, but since commercial materials were often impure, the quality of the finished pigments varied as well. The two commissioners stated:

\footnotetext{
${ }^{35}$ KPM archive XVII. 12, folio 10 [4].

${ }^{36}$ KPM archive XVII. 12, folio 18 [12]-32 [26].

${ }^{37} \mathrm{KPM}$ archive XVII. 12, folio 17 [11]-18 [12].

${ }^{38}$ KPM archive XVII. 12, folio 24 [18].

${ }^{39}$ KPM archive XVII. 12, folio 19 [13].
} 
In our opinion the preparation of invariably good pigments for the Royal Manufactory is too important for being always dependent on the accidental quality of their ingredients, according to what a merchant just has in stock. ${ }^{40}$

They recommended constructing a storeroom and stocking up ingredients for at least a whole year, and performing accurate quality tests of all materials.

The report also contained a long list of ingredients for pigments and fluxes as well as recipes for their preparation, which was part of the board's attempt to shift the Arcanum away from individual laboratory workers and toward the board of the Manufactory. ${ }^{41}$ The recipes were short, resembling the recipes presented in pharmacopoeias. Alongside information about the ingredients, quantities and the essentials of techniques and tools, for each single material Klaproth added personal information about the best place, or the best local artisan or merchant, from which to buy the purest materials. ${ }^{42} \mathrm{He}$ also offered his help to get access to pure copper and tin from overseas. This was one way in which the experienced apothecarychemist, who participated in an international commercial network, sought to improve manufacture. The high-quality materials required for the production of luxury goods could be obtained in another way: pure materials could be bought from a chemist. Thus Klaproth began to experiment with Magisterium plumbi, prepared in his own pharmaceutical laboratory, to be used as a substitute for minium, which was one of the board's main concerns. He also sold pure nitric acid to the Manufactory, ${ }^{43}$ and he recommended purchasing sal ammoniac from the chemist Friedrich A. C Gren, professor at the University of Halle. ${ }^{44}$ Many of the committee's suggestions for improvements were soon put into practice. As early as 20 August 1789, Grieninger junior, who was an assistant in the Manufactory's

\footnotetext{
${ }^{40}$ KPM archive XVII. 12, folio 19 [13].

${ }^{41}$ For this issue, see Ursula Klein, "Depersonalizing the Arcanum," forthcoming in Techology and Culture.

${ }^{42}$ KPM archive XVII. 12, folios 20 [14]-23 [17].

${ }^{43}$ KPM archive XVII. 12, folio 20 [14] and 38 [32].

${ }^{44}$ KPM archive XVII. 12, folio 20 [14] and 38 [32]. However trials at the Manufactory soon showed that this was not better than the material hitherto used, and more expensive. KPM archive XVII.12, folios 33 [27]-34 $[28]$.
} 
board, reported on the enlargement of the laboratory, which was necessary for installing a distillation retort, and the improvements of storage devices, as well as the purchase of many new barrels, glass vessels and tools. ${ }^{45}$

In addition to improvement of existing technology, the report also mentioned an invention: the use of "Plantina" (platinum) for ornamentation. A comment by Klaproth in the margins stated: "Plantina should be mentioned, which has been in use since the completion of the draft [of the report]." ${ }^{46}$ While Rosenstiel apparently failed to notice the first practical application of a substance that chemists had discovered only a few decades before, Klaproth reported his invention to the Royal Prussian Academy of Sciences, including a demonstration of samples of porcelain ornamented with platinum. ${ }^{47}$

The committee's report was signed by Rosenstiel and Klaproth but not by the Manufactory's arcanist Dr. Schopp, the third member of the committee. It seems that Schopp was too old or not willing to cooperate. In the meantime he had been replaced by the laboratory worker Friedrich Bergling, who would soon became the major experimenter for the inspecting committee.

\section{The Laboratory Worker Friedrich Bergling}

Friedrich Bergling (unknown-1797) had originally been an apothecary living in Berlin. In January 1788, the board of the Manufactory hired him as a laboratory assistant to be further trained as a true laboratory worker (Laborant). Bergling was to become the Manufactory's first laboratory worker, and later an arcanist, who was not only

\footnotetext{
${ }^{45}$ KPM archive XVII.12, folio 11 [5]-14 [8]. The expenses for the enlargement and improvement of the laboratory, listed by an accountant, amounted to 95 Thaler. KPM archive XVII.12, folio 35 [29].

${ }^{46}$ KPM archive XVII.12, folio 21 [15].

${ }^{47}$ Martin Heinrich Klaproth, “Über die Anwendbarkeit der Platina zu Verzierungen auf Porcelan,“ Mémoires de l'Académie Royale des Sciences et Belles-Lettres (1788-89): 12-15. In his report Klaproth described his technique of preparing and using platinum for ornamenting porcelain and recommended to use it as a substitute for silver, as silver did not sufficiently coat the porcelain and quickly lost its lustre. On the history of platinum see Bernhard Neumann, Die Metalle, Geschichte, Vorkommen und Gewinnung nebst ausführlicher Produktionsund Preis-Statistik (Halle: Verlag von Wilhem Knapp, 1904), 353-364.
} 
apprenticed to a technical official but also received formal chemical education and training. For the latter purpose Heinitz involved Klaproth.

As a first step, Heinitz asked Klaproth to examine Bergling's "chemical knowledge" and to send him an evaluating report. ${ }^{48}$ On 10 January 1788 Klaproth wrote back that he had examined Bergling. He also included a list of his questions along with Bergling's answers. All of the eight questions in his list concerned knowledge about substances, ranging from the way of their identification and classification to composition, characteristic reactions and techniques of preparation. For example, Klaproth asked Bergling how many species of earth were known and what was the main difference among them; what were the components of clay; what was a metal and so on. Klaproth concluded that "Although he does not lack skill and knowledge, he is still backward concerning the proper scientific part of chemistry." He added that Bergling was "more familiar with the part of chemistry belonging to the pharmaceutical discipline," and he recommended that Bergling should attend his own chemical course, combining it with "diligent reading of good textbooks," and at the same time he should perform some practical work in the laboratory of the Manufactory. For the latter, practical part of his training he further recommended keeping a notebook. He pointed out that in the notebook Bergling should "not only report the work itself but also pay attention, in accordance with chemical principles, to the reason of procedures, their success, and the observed phenomena." ${ }^{\circ 9}$

Heinitz immediately accepted Klaproth's recommendation, which implied a novel form of training laboratory workers and arcanists: a combination of practical training with formal instruction through textbooks and lectures. Moreover the practical

\footnotetext{
${ }^{48}$ KPM archive II.1, vol. 1 (Acta die Etablirung der Königlichen Porzellan Manufaktur-Commission ...betreffend), folio 28 [17|; KPM archive V 6 (Acta die Anstellung des Friedrich Bergling beim Laboratorio der Königlichen Porzellan Manufaktur betreffend), folio 2.

${ }^{49}$ KPM archive V.6, folio 3.
} 
training differed from traditional forms of apprenticeship in a significant aspect: the use of a notebook. When Klaproth emphasized that this would help Bergling to make observations and think about chemical procedures "in accordance with chemical principles," he pointed to the disciplinary essentials of chemistry and not to first causes or principles. Talk about "chemical principles" must be read in context. In this context, the term chemical principles refers to the ensemble of techniques, concepts and values that were broadly accepted in the chemical community. ${ }^{50}$

On 29 January 1788 Bergling became a laboratory assistant in the Manufactory and in spring 1789 he was promoted to the position of a laboratory worker, with an annual salary of 200 Thaler. One of his first duties was to write a report on the laboratory. On 29 May 1789 he was instructed to "apply the chemical knowledge and experience hitherto acquired to the perfection of the preparation of pigments, the invention of new pigments and fluxes and the most advantageous use of enamel fire." In addition he had to perform all preparations done in the laboratory and "clearly explain the reasons of the applied techniques." 51

Bergling's report of 16 June 1789 included a long list of items to be improved. ${ }^{52} \mathrm{He}$ identified various sources of impurity, in particular in the use and storage of river water and he recommended buying a big distillation retort for producing pure water. Poor quality filter paper rendered precipitated pigments impure and should be replaced with linen, the potash used for precipitating copper, cobalt and other metals was impure, instruments and vessels were not clean, and labels for naming substances were lacking. Many materials were not stored appropriately and the laboratory needed new pots, glass vessels, and a second furnace for smelting the fluxes. The board accepted almost all suggestions, making marginal comments such as "this shall be done for the sake of order and cleanliness." "53

\footnotetext{
${ }^{50}$ The meaning of the term "principles" here resonates with Thomas Kuhn's concept of disciplinary matrix.

${ }^{51}$ KPM archive V.6, folio 10.

${ }^{52}$ KPM archive XVII.12, folio 15 [9]-16 [10].

${ }^{53}$ KPM archive XVII.12, folio 16 [10]
} 
The report indicates that the values of the chemically-trained apothecary Bergling differed from those of the Manufactory's old laboratory worker Riedel. From Bergling's perspective, for a chemist in his laboratory, purity of materials, clean instruments and vessels, and well-ordered storage of materials were among the most important values. Chemists were used to experimenting with a plethora of different kinds of substances, and they were experienced in the problems caused by impurity and disorder. However, with the exception of apothecaries, there were no artisans at the time who would have worked with a similarly broad range of materials and possessed comparable values. The eighteenth-century chemist, like many scientific experimenters today, was both a technician and a savant, and it would be ahistorical if we tried to separate these two sides from each other.

Bergling's report from 16 June 1789 must have been the immediate incentive, or perhaps even the blueprint, of Rosenstiel and Klaproth's report that followed on 22 June (see above). Indeed, in an accompanying letter to the committee's report Rosenstiel remarked that his and Klaproth's own views “often coincide with Bergling's ideas." 54 This remark, like many similar ones, is indicative of the inspecting committee's style of working. The high mining official Rosenstiel and the savant Klaproth supported Bergling and collaborated with him rather than exploiting his handiwork for their own purposes. Although, the laboratory worker Bergling and the members of the inspection committee wrote their own reports, they mutually reinforced each other. Rosenstiel and Klaproth clearly regarded Bergling as an ally in their efforts to improve the laboratory and implement chemical expertise in practice.

\section{Collaboration of Chemical Experts}

Two years later, in April 1791, Bergling finished yet another long report for the Manufactory's board, concerned mainly with the preparation of pigments and fluxes to be

\footnotetext{
${ }^{54}$ KPM archive XVII.12, folio 17 [11].
} 
used for painting on porcelain. ${ }^{55}$ Around this time, he had become the most important experimenter for the Manufactory's inspecting committee. The style of his report was, in principle, the same as Rosenstiel and Klaproth's earlier report: the presentation of recipes. Bergling presented altogether 40 recipes for different pigments, fluxes and oils, which relied on numerous experimental trials and repetitions of trials, in which he had varied proportions of ingredients or techniques. Many of his recipes were considerably longer than Rosenstiel and Klaproth's, as they contained more detailed practical information as well as explanations of observations.

To give some examples of Bergling's explanations, he had observed a strong odour during the preparation of the flux to be used for ornamenting with gold. The ingredients used for the flux were equal proportions ( 1 Loth, ca. $16 \mathrm{~g})$ of pure sal ammoniac, pure saltpetre and calcinated borax. Bergling explained the odour by reconstructing the chemical reaction that took place. Borax, he explained, was over-satisfied with mineral alkali. When it was mixed with the other ingredients, its mineral alkali "displaces the volatile alkali of the sal ammoniac and combines itself with its salt acid [later hydrochloric acid]. ${ }^{, 56}$ The result of this reaction, he continued, was "sal digestivum" (potassium chloride) and "borax glass." In a similar way, he explained other observations with displacements of phlogiston or combinations with it. ${ }^{57}$ Bergling's explanations and talk about phlogiston manifests that he shared the "principles" of the chemical community, that is its understanding of "chemical reactions," including movements of invisible substances such phlogiston, which chemists considered to bea laboratory substance, comparable to air.

Six months later, on 19 September 1791, Rosenstiel sent a second report of the inspecting committee to the Board which begins:

\footnotetext{
${ }^{55}$ KPM archive XVII.12, folio 36 [30]- 49[43].

${ }^{56}$ Ibid., folio 38 [32].

${ }^{57}$ Ibid., folio 39 [33], 40 [34], 41 [35], 42 [36], 43 [37].
} 
Following the order of your Excellency [von Heinitz] I had a meeting with Professor Klaproth and Herr Bergling, and we have studied in fine detail Bergling's essays about the materials used in the laboratory of the Royal Porcelain Manufactory and about the preparation of fluxes for gold, silver and So on and of the pigments. ${ }^{58}$

Again, this statement, like many others, demonstrates that Klaproth and Rosenstiel regarded the laboratory worker Bergling as their collaborator. Far from enforcing Enlightenment savants' abstract scientific ideas onto the artisan, as some historians would have it, they first read his essay and thought about his ideas before they added their own ones. Although the laboratory worker and technical official clearly had a lower social status than the professor and the mining official, there is no indication that the latter would not have taken Bergling's report and suggestions very seriously.

From 1791 Klaproth and Bergling continually exchanged ideas about improvements of existing pigments. Klaproth made comments on Bergling's suggestions, written on the margins of the latter's report or in the committee's own report, but Bergling, too, commented on Klaproth's suggestions for improvement. At the same time Bergling and Klaproth still had a student-teacher relationship. Bergling asked Klaproth for advice and help when problems occurred (see below), and Klaproth continued to recommend books to him. ${ }^{59}$

Beginning in 1791, Bergling and Klaproth also performed more inventive experiments. These included the preparation of the pigment "gold purple" without the use of tin; the preparation of a darker "dark blue" by adding pyrolusite (natural manganese dioxide); the preparation of "dark yellow" with "regulus of antimony" instead of raw antimony; the preparation of "light brown" with sublimated zinc instead of calamine; and the preparation of darker "chestnut brown" by adding pyrolusite. Thus, for several recipes they substituted

\footnotetext{
${ }^{58}$ KPM archive XVII.12, folio 50 [44].

${ }^{59}$ KPM archive XVII.12, folio 53 [47].
} 
chemically-processed substances for raw materials. Klaproth also suggested testing entirely new pigments containing scheelite and lapis lazuli, as well as "uranium", which he had discovered in $1789 .{ }^{60}$ In three reports in 1792 Bergling presented his experiments and successfully prepared a new pigment with "uranium" as well as one with scheelite, which yielded "a nice yellow colour."

\section{Chemical Analysis of Porcelain Earths}

From late 1790 Bergling was further trained to become an Arcanist as well. He began to perform wet quantitative analyses of porcelain earths, which stemmed from different deposits, and of feldspar, quartz and some other kinds of stones. The Manufactory obtained its "porcelain earth" mainly from deposits near the town of Halle (from the deposits of Brachwitz, Beidersee, Morl and Sennewitz), but also from Silesia (deposit of Ströbel) and from the town of Passau, which had previously been its main supplier. Its feldspar stemmed from Silesian deposits (Krumhübel, Lomnitz, Schreibershau). ${ }^{62}$ The proportions of the components of raw minerals stemming from these different deposits, and from different parts of the same deposit, were never exactly the same. Yet knowledge about the chemical composition of the ingredients of porcelain paste was crucial for the success of manufacture. The wet quantitative chemical analysis of minerals - one of the most recent chemical methods - yielded the most exact knowledge in this respect. Around 1790 at the very latest, it became

\footnotetext{
${ }^{60}$ KPM archive XVII.12, folio 51 [45]-53 [47]. Klaproth's "uranium” was actually uranium trioxide (Martin Heinrich Klaproth, "Mémoire chimique et mineralogique sur l'Urane, Mémoires de L'académie royale des sciences et belles lettres (1786-87): 160-174 (it should be noted that the issue was back-dated; Klaproth presented the paper to the Academy on 24 September 1789. See Registres de l'Académie, archive BBAW I-IV32, folio 80).

${ }^{61} \mathrm{KPM}$ archive XVII.12, folio 54 [48]-56 [50], 57 [51]-58 [52] and 59 [53]. "Uranium yellow" (Urangelb) is mentioned in a table of porcelain colours from 1838 by the Manufactory's director Georg Friedrich C. Frick; see Köllmann and Jarchow, Berliner Porzellan, 323 (colour number 28 of the table).

${ }^{62}$ Kolbe, Geschichte, 151; Siebeneicker, Offizianten und Ouvriers, 99.
} 
a significant technique involved in the Manufactory's quality control of materials. Thus, one of the most advanced parts of chemical science became useful in manufacture. ${ }^{63}$

On 6 January 1791, Bergling submitted his first report on the wet quantitative analysis of four samples of porcelain earth from different deposits (Morl, Beidersee, Ströbel, and Passau). He had mixed a small sample (1 Loth) of each type of earth with a certain quantity of oil of vitriol and distilled water, cooked the mixture, purified the remaining material with hot distilled water and filtered it (several times). He identified the component not dissolved in this operation as "siliceous earth" and further determined its weight. He then isolated the dissolved components of the porcelain earth through precipitation with a solution of potash, which yielded "argillaceous earth" and a small proportion of "calcareous earth." Bergling showed that the four samples contained the same components - argillaceous earth (kaolin), siliceous earth (quartz), and (a small proportion of) calcareous earth - but in different proportions. ${ }^{64} \mathrm{~A}$ few weeks later he reported on similar analyses of feldspar, quartz and other stones. ${ }^{65}$

Bergling performed his analyses of porcelain earths and stones with Klaproth and another savant, the mineralogist and mining official Dietrich Ludwig Gustav Karsten (17681810). ${ }^{66}$ The would-be arcanist Bergling was learning by doing, but he was also instructed by two savants. Karsten, charged with this obligation by his superior Heinitz, first read Bergling's report and then commented on it in written form. This indirect way of communication led to some tensions and misunderstandings, not least since Karsten, the young mineralogist, had apparently no distinct experience in analysing "porcelain earths." In

\footnotetext{
${ }^{63}$ The question of whether the old Arcanisten Schopp and Manitius performed some kind of chemical analysis must remain an open one. The documents mention neither Schopp nor Manitius in this context.

${ }^{64}$ KMP archive XVII.12, folio 66 [60]-67 [61].

${ }^{65}$ KMP archive XVII.12, folio 68 [62].

${ }^{66}$ Karsten had first studied the mining sciences at the Mining Academy of Freiberg (from 1782-86) and then continued his studies for one year at the University of Halle. In 1789 he became a mining assistant in Heinitz's Mining and Smelting Department in Berlin, and began teaching mineralogy at the so-called Mining Academy. He was promoted to the position of a mining councillor in 1792 .
} 
his first report, Karsten doubted, in particular, that porcelain earths contained calcareous earth. "This is impossible," he wrote, "since this mixture would not yield porcelain but rather glass, according to all known chemical experience. ${ }^{967}$ He speculated that Bergling's samples of porcelain earths were not sufficiently purified, that his reagents were impure and that his utensils were not clean. He also wondered whether the quantity of the samples to be analysed was too small. But, although his report was critical, he ended with the reconciling remark that the substances involved in Bergling's experiments caused "the most difficulties in their analysis." He added that even "very good chemists, who are much more experienced, often made multifarious errors in this case." ${ }^{98}$ It was clear that, for Karsten, Bergling was doing chemistry.

The Board immediately forwarded Karsten's report to Bergling, along with the instruction that Bergling should repeat all of the analyses with larger quantities of substances and greater exactitude. ${ }^{69}$ On 3 March 1791 Bergling handed over a written response, which was partly a defence and partly an acceptance of Karsten's objections. He had contacted his mentor Klaproth, "talked to him in detail and also showed the earths to him"70 and obtained his support. He pointed out, for example, that professor Klaproth "had examined the calcareous earth in his presence and found that his results were correct and that the earth was pure calcareous earth." ${ }^{\gg 1}$ But Bergling had yet another, even stronger argument in his favour: "I took the vitriolic acid from professor Klaproth," he stated, "and I assumed it were certain that it is entirely pure, since it was destined for medical use." ${ }^{.72}$ On the other hand, he also conceded several times that he had erred and "that Herr assessor Karsten was right." ${ }^{, 73} \mathrm{He}$

\footnotetext{
${ }^{67}$ KMP archive XVII.12, folio 62 [56].

${ }^{68}$ KMP archive XVII.12, folio 65 [59].

${ }^{69}$ KMP archive XVII.12, folio 62 [56].

${ }^{70}$ KMP archive XVII.12, folio 70 [63].

${ }^{71}$ KMP archive XVII.12, folio 70 [63].

${ }^{72}$ Ibid.

${ }^{73}$ KMP archive XVII.12, folio 71 [64], 72 [65].
} 
ended stating: "it will always be the greatest encouragement for my service to be supported in my experiments by experienced chemists." 74

On May 261791 the King issued a "new Reglement for the personal of the Porcelain Manufactory in Berlin," which made the arcanist responsible for the entire technical work of the Manufactory, including the preparation of pigments and enamelling in the laboratory. ${ }^{75}$ This meant that the responsibility for the Manufactory's two Arcana - the preparation of the paste and of the pigments - was now to be unified in one hand. Clearly, Heinitz, the man behind this reglement, had definite ideas about the expert to be charged with the reorganised position. Hence, in June 1793, after the old arcanist Manitius had retired, Bergling was promoted to the position of an arcanist. In the following years, his greatest achievement was the introduction of "sanitary dishes (Gesundheitsgeschirr)", which he co-invented with the laboratory worker Johann George Roesch. ${ }^{76}$ In 1797 , he died unexpectedly. ${ }^{77}$

\section{Experiments on Vital Air with Alexander von Humboldt}

In March 1793 a novel type of experiment took place at the Manufactory. It studied the effect of "vital air" (oxygen) on enamelling. The experiment was ordered by Minister von Heinitz and performed by the Arcanist Berling and Alexander von Humboldt. At the time, Humboldt was a mining official in Prussian service. ${ }^{78}$ In his report from 5 March 1793 he wrote:

According to the oral order of his Excellency Fr. v. Heinitz to perform an experiment that studies the influence of the vital air, or the formerly so-called

\footnotetext{
${ }^{74}$ KMP archive XVII.12, folio 73 [66].

${ }^{75}$ GStA PK, I. HA Rep. 151, Finanzministerium, Abt. IC, Nr. 9469, folio 64-71.

${ }^{76}$ See Siebeneicker Offizianten und Ouvriers, 36-37, 99, 149, 486. The name of the new product, which contained a larger proportion of clay than China, referred to the fact that it was not glazed with lead compounds, which were poisonous. A similar product had been manufactured earlier in France. See Siebeneicker Offizianten und Ouvriers, 36-37.

${ }^{77}$ KPM archive V.6, folio 15, 25.

${ }^{78}$ Ursula Klein, “The Prussian Mining Official Alexander von Humboldt,” Annals of Science 69 (2012): 27-68.
} 
dephlogistated gas, on the smelting of pigments during enamelling, we have used two mornings last week for preparing the necessary quantity of vital air. ${ }^{79}$

The experiment itself, Humboldt further reported, was carried out on 5 March, at 11 a.m., in the presence of director Grieninger and professor Klaproth. Humboldt and Bergling first coated two dishes with green, blue, violet and red colour, put the dishes into a muffle, and then started firing. The furnace, which was presumably the small muffle-type furnace installed in the laboratory, was heated not with wood but with coal in this case. After fifteen minutes the two experimenters began to introduce the vital air. After half an hour, when ten quart of vital air had been consumed, enamelling was completed. The observed effects were not overwhelming: most of the colours did not differ from those obtained by ordinary enamelling, with the exception of red, which had no lustre.

“The success of this experiment," Humboldt concluded, is "at least negatively instructing. ${ }^{{ }^{80}}$ He then explained in more detail the two effects to be expected in the experiment: first, an increase of heat, and, second, changes in the shades of colour. Heinitz's goal had apparently been twofold: improvement of furnaces by using coal and improvement of enamelling.

The board of the Manufactory had long been concerned with the Manufactory's enormous consumption of wood and with its increasing shortage, and thus promoted experiments with coal and new types of furnaces. ${ }^{81}$ The introduction of vital air into the coal, Humboldt explained, indeed caused an increase of heat, since coal "combines with the radical (or basis) of the air, that is oxygen, so that its remaining components matter, of heat and light,

\footnotetext{
${ }^{79}$ KPM archive XVII.12, folio 60 [54].

${ }^{80}$ KPM archive XVII.12, 60 [54].

${ }^{81}$ Heinitz initiated studies of changes of furnaces as early as July 1787. See KPM archive XVII.27, folio 18 [13]-

21 [16]. See also Siebeneicker, Offizianten und Ouvrier.
} 
are set free." ${ }^{\$ 2}$ Here Humboldt applied Lavoisier's theory of combustion and composition of gases. ${ }^{83}$ Yet he was sceptical concerning the experiment's economic usefulness: "Would the consumption of gas not be more expensive that the saving of wood?" he asked. ${ }^{84}$

Concerning the effect of vital air on the shades of colours, Humboldt pointed out that the French chemists Claude Louis Berthollet and Antoine François Fourcroy had indeed proven that "metal calxes" - which he defined, according to Lavoisier's theory, as compounds consisting of a metal and the radical of oxygen - underwent changes of their colour in correlation with their saturation with oxygen. This confirmed the assumption that vital air might be somehow useful for ornamenting porcelain. Humboldt objected, however, that the role played by oxygen was limited to the formation of metal calxes or oxides (used as pigments) and did not extend to the subsequent process of enamelling. The chemical reaction underlying the latter process, he explained, was not oxidation but vitrifaction, and the vitrified surfaces prevented any additional interaction of oxygen with the metal.

When Heinitz had asked Humboldt to perform experiments on vital air he may have had some vague ideas about the usefulness of the experiments and of Lavoisier's chemistry more broadly. The Minister was clearly a man of the Enlightenment, but he was not a utopian dreamer. He was an eminently knowledgeable man, long experienced in the technicalities of mining and manufacture who had a quite pragmatic attitude towards chemistry and science in general. For example, he never wholeheartedly supported attempts to create a true mining academy in Berlin, since Berlin was a residential city and not a mining centre. Instead, he recommended promising young men such as Alexander von Humboldt to study at the Mining Academy of Freiberg, where 'theory,' that is formal teaching, was combined with 'practice':

\footnotetext{
${ }^{82}$ KPM archive XVII.12, folio 61 [55].

${ }^{83}$ Lavoisier postulated that gases (such as oxygen) were composed of an unknown material basis or "radical" and matter of heat or calorique; during combustion, the radical of oxygen would combine with the burning substance into an oxide, while the matter of heat was set free.

${ }^{84}$ KPM archive XVII.12, folio 61 [55].
} 
apprenticeship in mining. ${ }^{85}$ Heinitz's pragmatic attitude towards the use of science for manufacture included openness to various scientific approaches and to new science, such Lavoisier's. Thus a couple of months after Humbolt's experiments he wrote to the King: "my attempts to continually perfect the forms and ornamentation of porcelain ... imply the use of the newest discoveries of chemistry." ${ }^{86}$

Humboldt and Bergling's experiment indeed involved the newest chemistry, but it failed, just as numerous technological experiments would do so in the decades and centuries to come. Immediate success is not an appropriate criterion for answering the question of whether or not chemistry, or the sciences at large, played a role in eighteenth-century manufacture. Large-term effects may be even more important. As the historian of technology Marcus Popplow has pointed out recently, technological change is "an evolving process with lots of dead ends, aberrations, and learning processes." ${ }^{" 87}$ Or putting it in Humboldt's words, experiments can also be "negatively instructing."

\section{Conclusion}

Historians of science and of technology long took for granted that early modern manufacture (or technology) and 'science' (often identified with 'natural philosophy') were clearly separate enterprises. An important exception is the work of Clow and Clow. They argued that eighteenth-century pottery was a genuine site of chemistry. ${ }^{88}$ If we define chemistry (and alchemy) as both a practice and theory, or art and science (or early form of technoscience), however, the challenge for historians is to define more precisely what activities can count as chemistry in eighteenth-century pottery and what can not. Furthermore, we must analyse the ways in which not only chemical instruments and techniques permeated an artisanal site but

\footnotetext{
${ }^{85}$ Klein, Humboldt.

${ }^{86}$ GStA PK, I. HA, Rep. 151, Finanzministerim, Abt. IC, Nr. 9469, folio 33.

${ }^{87}$ See Popplow's concluding remarks in Marcus Popplow, "Knowledge Management to Exploit Agrarian Resources,” in Ursula Klein (ed.), “Artisanal-Scientific Experts," 413-433.

${ }^{88}$ Clow and Clow, Chemical Revolution, 293-326.
} 
also how chemical knowledge and the values of the chemist circulated across artisanal and academic sites.

The Royal Prussian Porcelain Manufactory was a site of manufacture with a high degree of division of labour. In addition to specialized workers and officials performing parts of manufacture that had no or very loose connections to chemistry, two types of "chemical experts" - not just artisans or craftsmen - were permanently involved in manufacture: the arcanists and laboratory workers.

In preparation of the manufacture of porcelain paste, the Arcanists submitted commercial ingredients to quality tests, involving, at least after the Manufactory's reorganization in 1786/7, the newest chemical-analytical techniques of the late eighteenthcentury: wet quantitative analysis. Based on their analytical knowledge about variations in the proportions of the components of ingredients, they then calculated and adjusted the proportions of ingredients for the mixing of porcelain paste. They further performed exploratory experiments in which they varied ingredients and their proportions in order to improve the quality of porcelain paste or invent new kinds of paste, as was the case in the invention of the Manufactory's "sanitary dishes."

Furthermore, the laboratory workers and arcanists continually re-examined the recipes for the preparation of pigments and fluxes, adjusted them in response to small variations in the composition of local ingredients and performed further experiments for inventing new pigments. Another concern of these experts was the construction of furnaces and the search for new kinds of fuel such as coal.

In addition to chemical analysis, techniques of preparation and knowledge about substances, values of chemistry came into play as well. To these belonged cleanliness and order of the laboratory, exactitude of analysis, purity of materials, disciplined observation and writing of reports. The Manufactory's chemical experts also possessed "theoretical" chemical 
knowledge in the sense of knowledge acquired through formal teaching and the reading of texts. The laboratory worker and later arcanist Bergling read chemical books and used chemical concepts, explanations and nomenclature in his experimental reports that circulated widely in the chemical community. Taken together, there was no other art and craft around 1800 , nor any other experimental philosophy or academic discipline, in which these values, techniques and knowledge were all united.

From early on, the Manufactory employed university-educated arcanists who were clearly recognized as chemists. Furthermore, the Manufactory's board involved well-known chemists and mineralogists as external experts. To the latter belonged, first of all, Klaproth as well as Karsten and A. v. Humboldt. The board further encouraged Prussian chemists and mineralogists - Klaproth, Karsten and Hermstaedt - to teach its technical officials and further to produce purer materials for the Manufactory.

In the case of the laboratory workers and arcanists with an artisanal background, such as Bergling, it may be less clear than in the case of Klaproth whether they were chemists or not. The first point to remember here, however, is the fact that the terms 'laboratory workers' (Laboranten) and 'arcanists' (Arcanisten) referred to professions, though in a very small social field, whereas chemistry was not a profession. Therefore it was not mutually exclusive to be an arcanist, or a laboratory worker, and at the same time a chemist. The question of who was recognized as a chemist in the late eighteenth- and early nineteenth-century is notoriously difficult to answer, as our overview of the period is necessarily incomplete. Furthermore, terminology varied over time, even in the same country and at the same place.

Whereas in the eighteenth century only the university-educated arcanists were also designated chemists, terminology changed shortly afterwards. During the French occupation, Rosenstiel, who was then president of the Manufactory's board and who knew French very well, wrote a memoir about the history of the Manufactory for the French. In this memoir, he spoke of the Manufactory's chemists, and even more specifically of the "chimistes de pate, de 
vernis et de couleurs;" he also designated the laboratory a "chemical laboratory." 89 In so doing, he adjusted his terminology to that of the French. The Royal Porcelain Manufactory of Sèvres employed two chemists in the eighteenth century, Jean Hellot and Pierre-Joseph Macquer. The two men were responsible for making the paste, but they were always designated académicien chimistes..$^{90}$

Above, I have described in detail the activities of the laboratory worker and later Arcanist Bergling as well as those of the chemistry professor and apothecary Klaproth. We have also seen that Klaproth was a teacher of Bergling and that the two men were close collaborators. It took several years of practice for Bergling to become an expert who possessed the distinct knowledge and skills of a laboratory worker and Arcanist of a porcelain manufactory. In a similar way, the apothecary-chemist Klaproth needed years to become more familiar with the particular technical challenges in porcelain manufacture. Klaproth was a famous chemical analyst, well acquainted with the analysis of minerals. Yet he too did not at first possess sufficient expertise about "porcelain earths," pigments and enamelling. Many chemists, with artisanal background or university-educated, were ignorant about this particular technology. In the context of technology and manufacture it would thus be more appropriate to speak not just of chemists but of a distinct type of chemical expert. After several years of practice, both Bergling and Klaproth were chemical experts in the manufacture of porcelain, comparable to other types of chemical experts, say for metallurgy or dyeing, who again possessed chemical knowledge and skills adapted to the specific demands of their practical field.

If we compare Bergling and Klaproth from a wider perspective, abstracted from their locally-limited activities in porcelain manufacture, I would argue as well that the differences

\footnotetext{
$30-31$.

${ }^{89}$ GStA PK, I. HA, Rep. 151 IC, Nr. 9469 (Acta die Porzellan-Manufactur in Berlin betreffend), folio

${ }^{90}$ See Lehman, "Macquer," 331. In the nineteenth-century, Gustav Kolbe, then director of the Porcelain Manufactory, had no qualms about calling Bergling a chemist; Kolbe, Geschichte, 192.
} 
in chemical knowledge and analytical skill between them were not categorical ones but differences only in degree. Had Bergling lived longer, the differences between him and the chemical savant Klaproth, whose analytical skills were certainly more accomplished and whose chemical knowledge was more comprehensive and systematic, may have disappeared completely. Despite such differences, however, it would be artificial to order these two men into different classes, placing the apothecary-chemist Klaproth in the class of savants and chemists, on the one hand, and the laboratory worker and Arcanist in the class of artisans, on the other. The promotion of technical expertise, first by the courts and then by the modern state bureaucracy, rather involved the creation of new types of practitioners, in chemistry and elsewhere, who cannot be captured with the ancient binary distinction between craftsmen or artisan, and scholar. Bergling's and Klaproth's chemistry, performed at the Royal Prussian Porcelain Manufactory, was a truly hybrid enterprise: a local art and a more global science transmitted through formal training and education, the reading of texts, and the collaboration of savant and artisanal chemical experts.

Acknowledgement: I thank my assistant Johannes Lotze for his great help with my archival work. I also thank John Perkins for his editing of the text. 